\title{
LEONARD J. KIRSCH, 1934-1977
}

Leonard J. Kirsch died unexpectedly of a heart attack on July 5, 1977. Only forty-two years old, he planned to celebrate his birthday the next day. Len was at the peak of his ability and had a very productive future ahead of him. Until his illness he had been working on a study of Karl Marx's "economic writings" and had hoped to complete his study within the next year or so. He was also preparing a study of current Soviet trade union practices for a conference at the Kennan Institute for Advanced Russian Studies. It was as a teacher, however, that Len was at his best. Voted the best instructor at the University of Massachusetts in Boston, where he was an associate professor and chairman of the Economics Department, Len had a reputation for attracting students all over the Boston area. At one time or another in his career, he had taught at Harvard, Tufts, Brandeis, Simmons, and Wellesley. The usual pattern was for a school such as Wellesley to call on Len to fill in at the last minute because of his adaptability and his way with students.

The dry statistics in no way convey Len's flair. He received his A.B. degree from the University of Pittsburgh in 1956. He then entered the Russian area program at Harvard and received an A.M. degree in 1958. He completed his study for the Ph.D. in economics in 1967 and wrote a dissertation entitled "A Study in Soviet Economics: Wage Administration and Structure in the USSR since 1956." This later served as the basis for his book, Soviet Wages, which was published by the MIT Press in 1972. He also wrote articles and numerous book reviews for several scholarly journals. Along with his wife Lena he was coeditor of the journal Prablems of Economics. He also served as a consultant for the UAW on its labor policies, and since the late 1950s had been an associate of the Russian Research Center at Harvard University.

He leaves his mother, Anne; his wife, Lena, whom he met while an IREX exchange student at Moscow University in 1960; and his daughter, Lara. His loss, however, is felt by more than his immediate family. The field of Soviet studies and economics teaching in the Boston area has suffered a premature loss.

This is not an ordinary necrology. But then Len was not an ordinary man.

\section{Marshall I. Goldman} Wellesley College

\section{JOSEF KORBEL, 1909-1977}

A few weeks after the publication of his last book, Twentieth-Century Czechoslovakia: The Meanings of Its History, the news spread that Professor Josef Korbel died on July 18 in Denver, his home since 1949.

Korbel was born on September 20, 1909 at Kyšperk in the poor, hilly northeastern area of Bohemia, which was known for producing enterprising and hard-working men. Energy and enterprise were Korbel's hallmarks. The stirring events of World War I, the disintegration of the Habsburg Empire, and the establishment of the Czechoslovak Republic in 1918, which Korbel witnessed as a boy, awakened in him an abiding interest in political and international affairs. After completing his secondary education, he matriculated in the Faculty of Law of Prague's Charles University, from which he was graduated with the degree of Doctor of Law in 1933. A year of study at the Paris Sorbonne (1928-29) and another year of military service (1933-34) stimulated his interest in war and diplomacy and prompted him to seek a career in the Czechoslovak 